\title{
Analysis of medico-social factors for return to work among patients presenting with haematological malignancy (adamantine): results of a 'pilot study'
}

\author{
Bénédicte Clin ${ }^{1,2,3^{*}} \mathbb{D}$, Natacha Heutte ${ }^{4,5}$, Mathilde Boulanger ${ }^{1}$, Xavier Troussard ${ }^{6,7}$, Edouard Cornet ${ }^{7}$, \\ Ghandi Laurent Damaj ${ }^{6}$, Véronique Bouvier ${ }^{1}$, Anne-Valérie Guizard ${ }^{1}$, Guy Launoy ${ }^{1,2}$ and Idlir Licaj ${ }^{1,5,8}$
}

\begin{abstract}
Objective: The aim of this study was to describe return to work determinants in patients with haematological malignancy.

Results: This medico-social pilot study included patients with haematological malignancy in the département of Calvados, aged 18 to 55 years, diagnosed between 1st January and 31st December 2010 and alive at 1st January 2015. Patients were identified via consultation of the Lower Normandy haematological malignancy Registry. They completed a specially developed self-questionnaire, in addition to validated questionnaires for anxiety-depression, quality of life and fatigue. Of the patients contacted, 50\% accepted to participate. The mean age at diagnosis was 49.8 years, and the majority of patients (79.2\%) was professionally active at the time of diagnosis. Only $64.9 \%$ of subjects had stopped work due to illness. The psychological impact (demonstrated anxiety) was significantly greater in men $(p=0.01)$. The majority of subjects returned to work after treatment $(80.7 \%)$ and among them, the mean duration of absence from work was 16.1 months. Only $52.6 \%$ of subjects had informed their occupational physician and $56.7 \%$ had benefited from a pre-return visit. The satisfactory response rate obtained is promising for the extension of the present project as a prospective multicentric study.
\end{abstract}

Keywords: Cancer, Haematological malignancy, Return to work, Occupational reintegration, Occupational health, Social inequalities

\section{Introduction}

Cancer is a public health issue affecting more than 380,000 subjects every year in France [1, 2]. In 2018, 45,000 new cases of haematological malignancy were diagnosed in mainland France, of which 25,000 (55\%) were males $[1,2]$. Heavy treatment and prolonged work

*Correspondence: benedicte.clin14@orange.fr; clin-b@chu-caen.f ${ }^{3}$ Occupational Health Department, Service de Santé au Travail et Pathologie Professionnelle, C.H.U. (University Hospital) Côte de Nacre, CHU Caen, Caen, France

Full list of author information is available at the end of the article stoppages are often required. Even if the global incidence of haematological malignancy is increasing, average patient survival is improving thanks to scientific progress, both in terms of screening and overall cancer care [2].

Factors that may impact the return to work, in particular the duration of sick leave and its social and occupational determinants, as well as the possible specific modalities of such return to work and the associated support offered to patients, are poorly documented $[3,4]$. The aim of the present study was to describe the 
modalities involved in returning to work after treatment in patients with haematological malignancy.

\section{Main text Methods}

The study population included professionally active patients (patients with a professional status) with haematological malignancy in Calvados, aged 18 to 55 years inclusive at the date of diagnosis of haematological malignancy, diagnosed between 1st January and 31st December 2010 and alive at 1st January 2015. Inclusion criteria associated: patients who were likely to return to work to the same job and patients who changed jobs. Self-employed subjects (with neither employer nor work colleagues) were excluded from the analysis. The identification of patients with haematological malignancy was conducted via consultation of the Lower Normandy haematological malignancy Registry. Consultation of the RNIPP (National Directory for the Identification of Natural Persons) was conducted by investigators from the cancer registry to ascertain the vital status of included patients.

Patients completed a self-questionnaire, accompanied with an information notice. If the patient did not respond within 8 weeks, a reminder was mailed. An identification list was established, associating each patient with an identification number.

The study was approved by the hospital ethics committee (Ethic Board approval no 15.093). All participants received information on the study and provided written informed consent.

Medical data included: date of diagnosis of haematological malignancy; tumour stage at diagnosis (Ann Arbor classification); initial treatment: type and duration of treatment; possible previous history of cancer(s) and/ or concomitant cancer; possible recurrence of a previously treated haematological malignancy; comorbidity factors at time of diagnosis and 3 years after diagnosis.

We developed a specific self-questionnaire (Additional file 1: Questionnaire S1), which was sent together with other validated questionnaires on anxiety-depression (validated French version of the HADS, Hospital Anxiety and Depression Scale [5, 6], quality of life, EORTC, European Organisation for Research and Treatment of Cancer QLQ-C30 questionnaire, in its validated French version [7] and fatigue (Multidimensional Fatigue Inventory, MFI).

The specifically developed questionnaire was developed from previous patient interviews as part of multidisciplinary cancer return-to-work consultations. This allowed us to select relevant items to used in the study questionnaire. This questionnaire included data on: patient sociodemographic characteristics (sex, age); socioprofessional data at the time of diagnosis and at the time of study, together with any potential change in this situation (occupied position, type of work contract, socioprofessional category, working conditions - in particular strenuousness and psychosocial risks, specific arrangements); potential socioprofessional difficulties associated with cancer (sick leave, financial support, disability recognition, etc.).

In order to study the factors associated with return to work as well as those related to employment preservation of patients, we compared 2 groups of subjects from our population. Group 1 consisted of subjects who had not ceased their professional activity and those who had resumed their professional activity after diagnosis; group 2 consisted of subjects who had not resumed their professional activity.

We calculated a 'Job Evaluation Score Prior to Diagnosis', which is the combination of the scores for each Job Evaluation Item prior to diagnosis. For each item: 0 points if 'not at all' or 'a little' in items 1, 2, 6, 8; or if 'moderately' or 'completely' in items $3,4,5,7.1$ mark if 'not at all' or 'a little' in items 3, 4, 5, 7; or if 'moderately' or 'completely' in items 1, 2, 6, 8.

Descriptive statistics were produced using Statistical Analysis System (SAS) software, version 9.3. Exploratory data analysis provided, for qualitative variables, their frequency and their 95\% confidence interval and, for quantitative variables, the mean, the standard deviation for the mean, the median and the quartiles. All missing data were systematically reported.

Statistical tests and confidence intervals have been calculated with a bilateral $\alpha=5 \%$.

The $\mathrm{Chi}^{2}$ test (or Fisher Exact Test depending on expected study population) was used to compare qualitative values and an ANOVA (analysis of variance) or Student's $t$ test (or Kruskal-Wallis and Wilcoxon test depending on specific cases) was used to compare quantitative variables. Results were considered significant if $\mathrm{p}<0.05$.

\section{Results}

The general characteristics of the 72 patients who accepted to participate are provided in Table 1 . The study population consisted of $45.8 \%$ women, mean age was 49.8 (9.5) years and the majority of subjects were active at the time of diagnosis, mostly under permanent contracts.

Among the active subjects at diagnosis $(\mathrm{N}$, number $=57(79.2 \%))$, the majority of subjects $(75.4 \%)$ were working full-time and on fixed day schedules. The average length of service was 15.7 years.

The majority of subjects (71.9\%) rated their professional activity prior to diagnosis as 'completely satisfactory', with no significant difference between men and 
Table 1 Study population characteristics $(n=72)$

\begin{tabular}{|c|c|c|c|}
\hline & $\mathrm{n}$ & $\%$ & $\begin{array}{l}\text { Mean } \\
\text { (standard } \\
\text { deviation) }\end{array}$ \\
\hline \multicolumn{4}{|l|}{ Gender } \\
\hline Men & 39 & 54.2 & \\
\hline Women & 33 & 45.8 & \\
\hline Age (years) & & & $49.8(9.5)$ \\
\hline$<50$ & 30 & 41.7 & \\
\hline$\geq 50$ & 42 & 45.8 & \\
\hline \multicolumn{4}{|l|}{ Diagnosis } \\
\hline Non-Hodgkin's lymphoma & 19 & 26.4 & \\
\hline Hodgkin's disease & 11 & 15.3 & \\
\hline Acute myeloid leukaemia & 9 & 12.5 & \\
\hline Multiple myeloma & 8 & 11.1 & \\
\hline Chronic lymphocytic leukaemia & 6 & 8.3 & \\
\hline MGUS & 6 & 8.3 & \\
\hline Acute lymphoid leukaemia & 1 & 1.4 & \\
\hline Chronic myeloid leukaemia & 1 & 1.4 & \\
\hline Other & 10 & 13.9 & \\
\hline Missing data & 1 & 1.4 & \\
\hline \multicolumn{4}{|l|}{ Treatments received } \\
\hline Chemotherapy & 45 & & 62.5 \\
\hline Therapeutic abstinence & 18 & & 25.0 \\
\hline Transplantation & 12 & & 16.7 \\
\hline Surgery & 11 & & 15.3 \\
\hline Radiotherapy & 2 & & 2.8 \\
\hline Other & 10 & & 13.9 \\
\hline
\end{tabular}

MGUS monoclonal gammopathy of undetermined significance

women, or between ages. Forty-two percent of the subjects declared that their professional activity involved a high psychological burden (in terms of time constraints and/or large quantities of work) and only $26.3 \%$ of subjects described a high physical burden. In terms of psychological support from co-workers, $43.9 \%$ of subjects declared themselves as 'well supported. $57.9 \%$ of patients considered they had sufficient freedom of movement in their work (responsibilities, satisfactory decision-making margins).

Only $64.9 \%$ of subjects reported a sick leave at diagnosis, no significant difference being observed in terms of age or sex. The average duration of sick leave for the entire study population was 19.9 months.

Almost half of patients (47.4\%) had not informed their occupational physician and $56.7 \%$ had benefited from a pre-return visit, no difference being observed for sex. There was an absence of adapted workstation layout for $90 \%$ of patients. The majority of subjects had resumed their professional activity in the same company as the one prior to diagnosis (65.2\%). The majority of subjects had taken up the same type of employment contract (86.7\%),
Table 2 Occupational situation AFTER diagnosis

\begin{tabular}{|c|c|c|c|c|}
\hline & Total & Men & Women & p-value* \\
\hline \multicolumn{4}{|c|}{ Disease-associated sick leave } & 1.0 \\
\hline Yes: $n(\%)$ & $37(64.9)$ & $19(63.3)$ & 18 (66.7) & \\
\hline No: (\%) & $18(31.6)$ & $9(30.0)$ & $9(33.3)$ & \\
\hline Missing data & $2(3.5)$ & $2(6.7)$ & - & \\
\hline $\begin{array}{l}\text { Duration of sick leave } \\
\text { (months): mean }\end{array}$ & 19.9 & 22.0 & 17.7 & 0.33 \\
\hline \multicolumn{4}{|c|}{ Occupational physician informed } & 0.10 \\
\hline Yes: n (\%) & $30(52.6)$ & $14(46.7)$ & $16(59.3)$ & \\
\hline No: n (\%) & $13(22.8)$ & $10(33.3)$ & $3(11.1)$ & \\
\hline Missing data & $14(24.6)$ & $6(20.0)$ & $8(29.6)$ & \\
\hline \multicolumn{4}{|c|}{ Pre-return consultation } & 0.42 \\
\hline Yes: n (\%) & $21(56.7)$ & $12(63.2)$ & $9(50.0)$ & \\
\hline No: n (\%) & $9(24.3)$ & $3(15.8)$ & $6(33.3)$ & \\
\hline Missing data: n (\%) & $7(18.9)$ & $4(21.0)$ & $3(16.7)$ & \\
\hline \multicolumn{4}{|l|}{ Return to work: n (\%) } & 1.0 \\
\hline Yes & $46(80.7)$ & $23(76.7)$ & $23(85.2)$ & \\
\hline No & $6(10.5)$ & $3(10.0)$ & $3(11.1)$ & \\
\hline Missing data & $5(8.8)$ & $4(3.3)$ & $1(3.7)$ & \\
\hline \multicolumn{4}{|c|}{ Return in the same company } & 0.66 \\
\hline Yes: n (\%) & $30(65.2)$ & $15(65.2)$ & $15(65.2)$ & \\
\hline No: n (\%) & $6(13.0)$ & $4(17.4)$ & $2(8.7)$ & \\
\hline Missing data n (\%) & $10(21.7)$ & $4(17.4)$ & $6(26.1)$ & \\
\hline \multicolumn{4}{|c|}{ Return to the same job } & 1.0 \\
\hline Yes: n (\%) & $25(83.3)$ & $13(86.7)$ & $12(80.0)$ & \\
\hline No: n (\%) & $5(16.7)$ & $2(13.3)$ & $3(20.0)$ & \\
\hline \multicolumn{4}{|c|}{ Return with the same employment contract } & 1.0 \\
\hline Yes: n (\%) & $26(86.7)$ & $13(86.7)$ & $13(86.7)$ & \\
\hline No: n (\%) & $1(3.3)$ & $1(6.7)$ & - & \\
\hline Missing data $\mathrm{n}(\%)$ & $3(10.0)$ & $1(6.7)$ & $2(13.3)$ & \\
\hline \multicolumn{4}{|c|}{ Adapted working hours } & 1.0 \\
\hline Yes: n (\%) & $3(10.0)$ & $2(13.3)$ & $1(6.7)$ & \\
\hline No: n (\%) & $27(90.0)$ & $13(86.7)$ & $14(93.3)$ & \\
\hline
\end{tabular}

* Chi square or Fisher test

and in the same job (83.3\%). Ninety percent of patients benefited from no adjustment to their working conditions. Arrangements for working conditions included: 'ergonomic adaptation of your workstation', 'arrangement of your workstation schedules' and 'other' (Table 2).

Of those who reported having a current occupation (Additional file 2: Table S1) $67.7 \%$ worked full-time. Return to work conditions were considered sufficiently anticipated for $59.2 \%$ of subjects, with no significant difference for age and sex.

The majority of subjects rated the current occupational activity as 'completely' satisfactory (62.1\%), and 10.3\% rated it as 'not at all' satisfactory. The analysis shows no significant difference for age and sex. The majority of subjects reported feeling more tired at work than before 
('completely' for $39.3 \%$, 'moderately' for $25 \%$, 'a little' for $17.8 \%$, and 'not at all' for $17.8 \%$ ), with no significant difference in age and sex.

The majority of subjects reported feeling that they were working 'the same as before' when they discovered their disease (71.4\%), and $25.0 \%$ reported feeling that they were working 'less than before' when they discovered their disease, with no significant difference for age or sex. Of those returning to work, $17.8 \%$ reported feeling penalised in their work because of their illness. No significant age and sex differences were observed (Additional file 2: Table S1).

Psychological impact was significantly greater in men (demonstrated anxiety disorder 73.0 versus 41.4 , $\mathrm{p}=0.001$ ), but no differences were observed for age.

Regarding the depression score, $65.6 \%$ of subjects had 'suspected depressive disorders' and $28.1 \%$ had 'proven depressive disorders'

The average score for the overall health and quality of life scale was 65.9/100. No significant differences in these items were found for age and sex. For the assessment of fatigue, the average score was 55.5/100. There was no significant difference for sex, age, overall or sub-scale (Additional file 2: Table S1).

There were no significant differences between Group 1 (subjects who had not ceased their professional activity) and group 2 (subjects who had not resumed their professional activity) for sex, age, length of service, type of employment contract, social protection scheme, working time and working hours (Table 3). The mean duration of absence from work among those who returned to work was 16.1 months (3.1) versus 42.2 months (8.2) for the group $2(\mathrm{p}=0.002)$.

The 'Job Evaluation Score Prior to Diagnosis' (which is the sum of the scores for each Job Evaluation Item prior to diagnosis), was not significantly different for the 2 groups studied $(\mathrm{p}=0.08)$. In contrast, for the assessment of fatigue, the average score was significantly higher among subjects who did not return to work $(\mathrm{p}=0.004)$ (Table 3).

\section{Discussion}

Unemployment after cancer represents a challenge for both the patient and the society [8] especially when the disease affects a young and previously active population. Studies have demonstrated that the absence of professional activity in these patients may, in particular, lead to impaired quality of life and general state of health, with the risked outcome of social exclusion [9-16]. A metaanalysis based on 36 studies focusing on the relationship between cancer and employment status $[17,18]$, including 20,366 cancer survivors and 157,603 healthy controls, demonstrated a higher proportion of unemployment
Table 3 Analysis of obstacles to job retention $(n=52)$

\begin{tabular}{|c|c|c|c|}
\hline & Group $1^{b}$ & Group $2^{b}$ & p-value* \\
\hline Number of subjects & 46 & 6 & \\
\hline \multicolumn{3}{|l|}{ Sex } & 1.0 \\
\hline Men: n (\%) & $23(50)$ & $3(50)$ & \\
\hline Women: n (\%) & $23(50)$ & $3(50)$ & \\
\hline Mean age (SD*) (years) & $49.8(9.2)$ & $52.5(4.4)$ & 0.73 \\
\hline Length of service (years) (SD) & $16.5(12.5)$ & $15.8(7.4)$ & 0.84 \\
\hline \multicolumn{3}{|l|}{ Social security scheme } & 1.0 \\
\hline General: n (\%) & 31 & 4 & \\
\hline Farming: n (\%) & 3 & 0 & \\
\hline Civil service: n (\%) & 6 & 2 & \\
\hline Self-employed: n (\%) & 2 & 0 & \\
\hline Other: $\mathrm{n}(\%)$ & 2 & 0 & \\
\hline Missing data: n(\%) & 2 & - & \\
\hline $\begin{array}{l}\text { Duration of sick leave (months): } \\
\text { mean }\end{array}$ & 16.1 & 42.2 & 0.002 \\
\hline \multicolumn{3}{|l|}{ Type of employment contract } & 1.0 \\
\hline Permanent: $\mathrm{n}(\%)$ & 30 & 5 & \\
\hline Fixed term: n (\%) & 5 & 0 & \\
\hline Temporary: n (\%) & 2 & 0 & \\
\hline Other: n (\%) & 5 & 1 & \\
\hline Missing data: n (\%) & 4 & - & \\
\hline \multicolumn{3}{|l|}{ Working basis } & 0.58 \\
\hline Full-time: n (\%) & 35 & 4 & \\
\hline Part-time: n (\%) & 6 & 1 & \\
\hline Missing data: n (\%) & 5 & 1 & \\
\hline \multicolumn{3}{|l|}{ Working hours } & 0.65 \\
\hline Set day hours: $\mathrm{n}(\%)$ & 27 & 5 & \\
\hline Set night hours: $\mathrm{n}(\%)$ & 1 & 0 & \\
\hline Morning/afternoon shifts: $\mathrm{n}(\%)$ & 7 & 1 & \\
\hline Day/night shifts: n (\%) & 2 & 0 & \\
\hline Other: $\mathrm{n}(\%)$ & 3 & 0 & \\
\hline Missing data: $n(\%)$ & 6 & - & \\
\hline \multicolumn{3}{|c|}{ Professional activity considered SATISFYING } & 1.0 \\
\hline Not at all: n (\%) & 3 & 0 & \\
\hline A little: $n(\%)$ & 1 & 0 & \\
\hline Moderately: n (\%) & 10 & 1 & \\
\hline Completely: n (\%) & 32 & 5 & \\
\hline \multicolumn{3}{|c|}{ Professional activity considered FULFILLING } & 1.0 \\
\hline Not at all: n (\%) & 2 & 0 & \\
\hline A little: $n(\%)$ & 3 & 0 & \\
\hline Moderately: n (\%) & 14 & 2 & \\
\hline Completely: n (\%) & 27 & 4 & \\
\hline \multicolumn{2}{|l|}{ Sensation of FATIGUE at work } & & 0.08 \\
\hline Not at all: n (\%) & 8 & 0 & \\
\hline A little: n (\%) & 19 & 1 & \\
\hline Moderately: n (\%) & 12 & 2 & \\
\hline Completely: n (\%) & 7 & 3 & \\
\hline \multicolumn{3}{|c|}{ High PSYCHOLOGICAL burden at work } & 0.07 \\
\hline Not at all: n (\%) & 6 & 0 & \\
\hline A little: $n(\%)$ & 13 & 0 & \\
\hline
\end{tabular}


Table 3 (continued)

\begin{tabular}{|c|c|c|c|}
\hline & Group $1^{b}$ & Group $2^{b}$ & p-value* \\
\hline Moderately: n (\%) & 6 & 4 & \\
\hline Completely: n (\%) & 20 & 2 & \\
\hline Données manquantes: n (\%) & 1 & - & \\
\hline High PHYSICAL burden at work & & & 0.08 \\
\hline Not at all: n (\%) & 17 & 2 & \\
\hline A little: n (\%) & 16 & 0 & \\
\hline Moderately: n (\%) & 3 & 2 & \\
\hline Completely: n (\%) & 10 & 2 & \\
\hline Support from co-workers & & & 0.38 \\
\hline Not at all: n (\%) & 9 & 0 & \\
\hline A little: n (\%) & 11 & 1 & \\
\hline Moderately: n (\%) & 6 & 0 & \\
\hline Completely: n (\%) & 19 & 5 & \\
\hline \multicolumn{2}{|l|}{ Job Evaluation Score Prior to Diagnosis ${ }^{\mathrm{a}}$} & & 0,08 \\
\hline$\leq 5: \mathrm{n}(\%)$ & 17 & 5 & \\
\hline$>5: \mathrm{n}(\%)$ & 26 & 1 & \\
\hline Missing data: $\mathrm{n}(\%)$ & 3 & - & \\
\hline Mean MFI score (standard deviation) & $51.8(16.2)$ & $68.5(6.50)$ & 0.004 \\
\hline \multicolumn{4}{|c|}{${ }^{*}$ Chi square or Fisher test } \\
\hline \multicolumn{4}{|c|}{$\begin{array}{l}\text { a Sum of the scores for each work evaluation item before diagnosis. For each } \\
\text { item: } 0 \text { points if 'not at all' or 'a little' in items 1,2, 6, 8; or if 'moderately' or } \\
\text { 'completely' in items } 3,4,5,7.1 \text { mark if 'not at all' or 'a little' in items 3, 4, 5, 7; or if } \\
\text { 'moderately' or 'completely' in items } 1,2,6,8\end{array}$} \\
\hline \multicolumn{4}{|c|}{$\begin{array}{l}{ }^{\mathrm{b}} \text { Group 1: subjects who had not ceased their professional activity and those } \\
\text { who had resumed their professional activity after diagnosis }\end{array}$} \\
\hline
\end{tabular}

among subjects with cancer compared to controls (33.8\% vs. $15.2 \%)$.

We observed that $79.2 \%$ of patients were professionally active at the time of diagnosis and only $64.9 \%$ had stopped work due to their illness. The majority of subjects returned to work after treatment (80.7\%). A study conducted in Denmark among 1741 patients with haematological malignancy between 2000 and 2007 [19] demonstrated that only 1140 subjects (i.e. $65 \%$ ) returned to work. Another study, including 130 patients with haematological malignancy and treated by haematopoietic cell transplant, professionally active at the time of diagnosis, demonstrated that, among the 88 surviving subjects 5 years later, $60 \%$ had returned to full-time and $32 \%$ to part-time work. Return to work was significantly higher in men than women (HR 0.54, 95\% CI 0.29-0.99) [20]. In our study, we included 6 cases of MGUS: this disease often had a small impact on general status and professional life. This may explain the higher rate of return to work observed in our study.

Other studies have observed that the longer the sick leave, the more difficult the return to work among patients suffering from cancer, hence highlighting the importance of early medico-social intervention $[3,4]$. In our study, the mean duration of the absence from work among subjects who returned to work was 16.1 months vs 42.2 months for the group which had not returned to work $(p=0.002)$. This encourages patients to quickly seek employment adaptations, and to consider well in advance the possible layout of their workstation, in order to anticipate recovery and avoid occupational exclusion.

The role of the occupational physician in the return to work for cancer patients has been previously demonstrated and a significantly higher level of return to work was observed in patients who benefited from arrangements in their working conditions [21, 22]. Unfortunately, according to another study, only one in 4 patients benefited from a consultation with the occupational physician immediately prior to return to work and only $50 \%$ benefited from special work arrangements [22]. Similarly, we found that almost half of patients had not informed their occupational physician about their disease and that $56.7 \%$ had benefited from a pre-return consultation. As a result, $90.0 \%$ of subjects did not benefit from any adjustment to their working conditions.

\section{Limitations}

One of the limitations of our pilot study is its low statistical power, which has not allowed us to analyse other determinants of job retention such as occupational category, education level and income level. Some factors were close to significant (psychological burden and physical burden between subjects who had returned to work or not, in particular). The results of the present pilot study will allow us to make proper statistical power estimation about the size of each working group.

The originality of our study was to exhaustively recruit all subjects with haematologic malignancies from a wellknown regional cancer registry. This ensures the completeness and reliability of diagnosis.

This study yielded promising results which led to its extension to include other medical centres. The results of this study should enable the widespread dissemination of information and the development of tools to identify factors of social vulnerability for professionals and associations involved in accompanying patients presenting with haematological malignancy.

\section{Supplementary information}

Supplementary information accompanies this paper at https://doi. org/10.1186/s13104-020-05149-4.

Additional file 1. Study self-questionnaire.

Additional file 2: Table S1. CURRENT occupational situation $(n=46)$. 


\begin{abstract}
Abbreviations
ANOVA: Analysis of variance; EORTC: European Organisation for Research and Treatment of Cancer; HADS: Hospital Anxiety and Depression Scale; MFI: Multidimensional Fatigue Inventory; N: Number; RNIPP: National Directory for the Identification of Natural Persons; SAS: Statistical Analysis System; SD: Standard deviation.
\end{abstract}

\section{Acknowledgements}

Not applicable.

\section{Authors' contributions}

Conception or design of the work: BC, VB, GL, XT. The acquisition, analysis, or interpretation of data for the work: $\mathrm{BC}, \mathrm{NH}, \mathrm{MB}, \mathrm{IL}$. Drafting the work or revising it critically for important intellectual content: BC, NH, MB, XT, EC, GD, VB, AVG, $G L, I L$. All authors read and approved the final manuscript.

\section{Funding}

This work was supported by the Cancéropôle Nord-Ouest and the funding obtained within the framework of the 'Support for Emerging Projects' call for proposals in 2014

\section{Availability of data and materials}

The datasets used and/or analysed during the current study are available from the corresponding author on reasonable request.

\section{Ethics approval and consent to participate}

Approval from the CPP Nord-Ouest (committee for the protection of human subjects) obtained 24/11/2014, approval from the CCTIRS (Consultative Committee for Data Processing in Health Research) obtained 11/02/2015, CNIL (National Commission for Data Processing and Liberties) approval obtained 07/08/2015. All participants received information on the study and provided their written informed consent.

\section{Consent for publication}

Not applicable.

\section{Competing interests}

The authors declare that they have no competing interests.

\section{Author details}

${ }^{1}$ INSERM U1086 «ANTICIPE », 14033 Caen Cedex, France. ${ }^{2}$ Université de Caen Normandie, Caen, France. ${ }^{3}$ Occupational Health Department, Service de Santé au Travail et Pathologie Professionnelle, C.H.U. (University Hospital) Côte de Nacre, CHU Caen, Caen, France. ${ }^{4}$ CETAPS EA3832, Université de Rouen, Mont-Saint-Aignan, France. ${ }^{5}$ Clinical Research Department, Centre François Baclesse, Caen, France. ${ }^{6}$ Service d'Hématologie Clinique, CHU de Caen, Caen, France. ${ }^{7}$ Registre des Hémopathies Malignes de Basse-Normandie, Caen, France. ${ }^{8}$ Department of Community Medicine, Faculty of Health Sciences, The UiT Arctic University of Norway, Tromsø, Norway.

Received: 21 April 2020 Accepted: 19 June 2020

Published online: 02 July 2020

\section{References}

1. Jéhannin-Ligier K, Dantony E, Bossard N, Molinié F, Defossez G, Daubisse-Marliac L, et al. Projection de l'incidence et de la mortalité par cancer en France métropolitaine en 2017. Rapport technique. Saint-Maurice : Santé publique France, 2017. p. 80.

2. Defossez G, Leguyader-Peyrou S, Uhry Z, Grosclaude P, Remontet L, Colonna M, Dantony E, Delafosse P, Molinié F, Woronoff AS, Bouvier AM, Bossard N, Monnereau A. Estimations nationales de l'incidence et de la mortalité par cancer en France Métroplolitaine entre 1990 et 2018. Etude à partir des registres des cancers du réseau Francim. Résultats préliminaires. Synthèse. Saint-Maurice (Fra): Santé Publique France; 2019. p. 19
3. Quinton-Fantoni S, Peugniez C, Duhamel A, Skrzypczak J, Frimat P, Leroyer A. factors related to return to work by women with breast cancer in Northern France. J Occup Rehabil. 2010;20:49-58.

4. Peugniez C, Fantoni S, Leroyer A, Skrzypczak J, Duprey M, Bonneterre J. Return to work after treatment for breast cancer: single center experience in a cohort of 273 patients. Bull Cancer. 2011;98(7):E69-79.

5. Zigmond AS, Snaith RP. The hospital anxiety and depression scale. Acta Psychiatr Scand. 1983;67(6):361-70.

6. Razavi D, Delvaux N, Farvacques C, Robaye E. Validation de la version française de HADS dans une population de patients cancéreux hospitalisés. Revue Psychologie Appliquée. 1989;4(39):295-307.

7. Aaronson NK, Ahmedzai S, Bergman B, Bullinger M, Cull A, Duez NJ, Filiberti A, Flechtner H, Fleishman SB, de Haes JC, et al. The European Organization for Research and Treatment of Cancer QLQ-C30: a qualityof-life instrument for use in international clinical trials in oncology. J Natl Cancer Inst. 1993;85(5):365-76.

8. Van Muijen P, et al. Predictors of return to work and employment in cancer survivors: a systematic review. Eur J Cancer Care. 2013;22:144-60.

9. Short PF, Vargo MM. Responding to employment concerns of cancer survivors. J Clin Oncol. 2006;24(32):5138-41.

10. Taskila T, Lindbohm ML, Martikainen R, Lehto US, Hakanen J, Hietanen P. Cancer survivors' received and needed social support from their work place and the occupational health services. Support Care Cancer. 2006;14(5):427-35.

11. De Jong M, Tamminga SJ, Frings-Dresen MH, de Boer AG. Quality of Working Life of cancer survivors: associations with health- and work-related variables. Support Care Cancer. 2017;25(5):1475-84.

12. Kennedy F, Haslam C, Munir F, Pryce J. Returning to work following cancer: a qualitative exploratory study into the experience of returning to work following cancer. Eur J Cancer Care. 2007;16(1):17-25.

13. Paraponaris A, Ventelou B, Malavolti L, Eichenbaum-Voline S. Le maintien dans l'activité et dans l'emploi. In Drees Inserm La vie deux ans après le diagnostic de cancer, coord. par Le Corroller-Soriane AG, Malavolti L, Mermilliod C. La documentation française, coll Etudes et statistiques, Paris. 2008.

14. Paraponaris A, Teyssier LS, Ventelou B. Job tenure and self-reported workplace discrimination for cancer survivors 2 years after diagnosis: does employment legislation matter? Health Policy. 2010;98(2-3):144-55.

15. Mehnert A. Employment and work-related issues in cancer survivors. Crit Rev Oncol Hematol. 2011;77(2):109-30.

16. Amir Z, Brock J. Cancer survivor and employment: epidemiology. Occup Med. 2009;59:373-7.

17. De Boer AG, Frings-Dresen MH. Employment and the common cancers: return to work of cancer survivors. Occup Med. 2009;59:378-80.

18. De Boer AG, Taskila T, Ojajärvi A, van Dijk FJ, Verbeek JH. Cancer survivors and unemployment: a meta-analysis and meta-regression. JAMA. 2009;301(7):753-62.

19. Horsboel TA, Nielsen CV, Nielsen B, Jensen C, Andersen NT, de Thurah A. Type of hematological malignancy is crucial for the return to work prognosis: a register-based cohort study. J Cancer Surviv. 2013;7(4):614-23.

20. Kirchhoff AC, Leisenring W, Syrjala KL. Prospective predictors of return to work in the 5 years after hematopoietic cell transplantation. J Cancer Surviv. 2010:4(1):33-44.

21. Waser AM, Chassaing K. Travailler autrement. Comment le cancer initie un autre rapport au travail, Revue internationale de psychopathologie et psychodynamique du travail, 2010, no 23.

22. Sevellec M, Bourrillon MF, Le Bideau S, Stakowski H, Le Peltier N, Morvan E, Belin L, Morvan E, Asselain B. Étude sur les répercussions du cancer sur la vie professionnelle, réalisée auprès de 402 salariés en île-de-France en 2008 avec 82 médecins du travail de la société de médecine du travail Ouest Île-de-France (SMTOIF).

\section{Publisher's Note}

Springer Nature remains neutral with regard to jurisdictional claims in published maps and institutional affiliations. 